\title{
Perceived Deception in Advertising: Proposition of a Measurement Scale
}

\author{
Sawssen Garbouj Chaouachi and Kaouther Saied Ben Rached
}

FSEG of Tunis, University of Tunis El Manar, Research Laboratory ERMA, Tunisia

\begin{abstract}
This paper suggests and tests a scale to measure perceived deception in advertising based on the recommendations of Churchill (1979) and Gerbing and Anderson (1988). A literature review and a qualitative study allowed us to generate a set of items. The results of two studies, based on a sample of Tunisian consumers, allowed us to identify a two-dimensional structure. Reliability and validity were confirmed.
\end{abstract}

Keywords: deceptive advertising, perceived deception, ethic, measurement scale.

\section{Introduction}

Deception has been the focus of many researchers in different disciplines such as psychology (Ekman and Friesen, 1969), psychiatry (Ford, 1996), human communication (McCornack, 1992) and more recently Internet (Grazioli and Jarvenpaa, 2003; Román, 2007). In marketing, and particularly in the field of advertising, deception is widely practiced by advertisers. It is justified by the positive impact it could have on sales volume (Estrada, 2006) and its effects on the evaluation of product attributes (Olson and Dover, 1978).

Deception is considered as one of the major ethical issues to be raised in advertising (Hyman, Tansey and Clarc, 1994). Indeed, it influences consumers' beliefs in a dishonest way and can have negative consequences on their financial resources and their health (Boush, Friestad and Wright, 2009). It also affects competition by the influence of consumer choice (Lord and Kim, 1995) and results in an increase in market transaction costs (Gao, 2008).

Today, consumers are increasingly warned against such practices especially by consumers' protection agencies, which leave them less vulnerable and increase their perception of deception. So, even if companies and advertisers may obtain some benefits of deception, their losses can be enormous. According to Darke and Ritchie (2007), the feeling of being duped influences the present and the future behaviour of the consumer. Romani (2006) has studied consumers' reactions to advertisements containing misleading information about price. Results show that levels of trustworthiness towards the source of information and willingness to buy decreased in the presence of deception.

The objective of this research is to develop and validate a scale to measure the perception of deception in advertising. Starting from the limitations of the existing measures, we will develop a measurement scale based on the paradigm of Churchill (1979) and Gerbing and Anderson (1988).

\section{Literature Review}

Deception has been studied in many disciplines. To reach a better understanding of this concept, a review of the literature in interpersonal communication and in advertising will be elaborated.

Copyright (C) 2012 Sawssen Garbouj Chaouachi and Kaouther SAIED BEN RACHED. This is an open access article distributed under the Creative Commons Attribution License unported 3.0, which permits unrestricted use, distribution, and reproduction in any medium, provided that original work is properly cited. Contact author: Sawssen GARBOUJ CHAOUACHI E-mail: Sawssen_garbouj@yahoo.fr 


\section{Deception in the Field of Interpersonal Communication}

Research in social psychology argues that deception is a phenomenon that is a part of the daily life of man (Vrij et al., 2010; DePaulo et al., 2003). Some think it is even necessary in life (Kerr, 1990) because it plays an important role in man's coping and survival in society (Serban, 2001). Masip, Garrido and Herrero (2004, p.148) describe interpersonal deception as "the deliberate attempt, whether successful or not, to conceal, fabricate, and/or manipulate in any other way factual and/or emotional information, by verbal and/or nonverbal means, in order to create or maintain in another or in others a belief that the communicator considers false".

Despite the large number of definitions developed in the field of interpersonal communication, they all agree on certain characteristics of deception:

\section{$>$ Deception Is an Intentional Act:}

As noted by Buller and Burgoon (1996), deception is "a deliberate message conveyed to a sender to create a false belief or conclusion at the receiver". That is, the presence of a deliberate intention to deceive is considered essential for the realization of deception. It is in fact a way to distinguish between false information intended to mislead other persons and false information provided because of problems of memory or incompetence (Massip and al., 2004). Indeed, false information provided involuntarily is described as an "honest error" (Miller, 1983), "unconscious and unintended" (Köhnken, 1989).

However, the criterion of intentionality poses some problems which are mainly related to the difficulty of detecting the true intentions of the communicator. Thus, past studies have examined several methods of deception detection. The theory of Deception Cues (Ekman and Friesen, 1969) is one of the first that focused on signs that can betray a liar such as facial expressions (Ekman and Friesen, 1969) or emotions (Ekman, 1992).

\section{$>$ The Communicator Considers the Information Transmitted as False:}

The perception that the sender has of reality is important. In fact, he must believe that the false information provided is different from the reality. Otherwise, it will be considered as a persuasive communication not deception (Massip et al., 2004).

\section{$>$ Deception Has an Instrumental Purpose:}

Deception is not an end in itself but a means to achieve goals that can benefit to the deceiver himself or to another person (Buller and Burgoon, 1996) and result from desire to gain esteem, respect or to obtain material gain.

\section{Deception in Advertising}

The conceptualisation of deception in advertising has been the subject of disagreement (Gao, 2008) drawn predominantly from a confusion between the jurisprudential, scientific and ordinary meanings of deception (Russo, Metcalf et Stephens, 1981). Indeed, researchers have examined deception, deceptiveness and legal deception. In fact, deception is a practice sanctioned and regulated by law. In the United States, where the majority of works on deception has grown, the Federal Trade Commission (FTC) defines deception as any "representation, omission or practice that is likely to mislead the consumer acting reasonably in the circumstances, to the consumer's detriment" (FTC, 1983). From a legal perspective, the claim must be important to the consumer's purchase decision to be considered as deceptive. Regulators observe the capacity of a claim to deceive (deceptiveness) rather than actual deception (Richards, 1990).

Definitions adopted by academic researchers were based on the cognitive effects of being mislead from the consumer's standpoint. In this sense, Gardner (1975) considers that deception is a behavioural construct which occurs "if an advertisement leaves the consumer with an 
impression(s) and/or belief(s) different from what would normally be expected if the consumer had reasonable knowledge, and that impression(s) and/or belief(s) is factually untrue or potentially misleading, then deception is said to exist". In the same reasoning, Olson and Dover (1978) stated that "deception occurs when consumers acquire demonstrably false beliefs as a function of exposure to an advertisement".

Hyman (1990) proposed a unique definition that can be adopted by researchers, lawyers and regulators. He considers that an advertisement is misleading "if it (i) contains a believable claim that is blatant or an unconscionable lie, (ii) encourages a discrepancy between what purchasers or purchase influencers believe to be claimed in the advertisement and what is fact and (iii) encourages the purchaser or purchase influencer to build upon previously held erroneous beliefs, so that their viewing of the advertisement interacts with these prior beliefs to produce (or reinforce) one or more erroneous beliefs".

From a social perspective, Aditya (2001) defined deception in marketing as "any act, claim or message that (a) causes at least some consumers acting reasonably to make decisions that they would not otherwise make, (b) leads at least some consumers acting reasonably to believe something about the product, brand or manufacturer that is not verifiably true or (c) has the potential to foster distrust of any kind, general or specific, or in other ways causes an erosion of ethical values deemed desirable in society".

Despite differences in the conceptualization of deception in advertising, some common features can be identified:

- Deception can be observed after exposure to an advertisement.

- It creates beliefs and interpretations about the product or service being advertised that are false.
- Unlike deception in the context of human communication, the element of intentionality is not necessary for the realization of deception in advertising.

\section{Types of Deception in Advertising}

Several classifications can be observed in the literature (Armstrong and McLennan, 1973; Grdner, 1975; Armstrong and Russ, 1981; Richards, 1990). Mainly, two forms of deception in advertising can be identified:

- Explicit Deception: the message contains expressly false information. In this case, deception can be detected by comparing the actual characteristics of the product and the message content.

- Implicit Deception: it occurs when the advertising message contains information that is literally true but leads the consumer to draw erroneous inferences about the product or the service attributes. Hastak and Mazis (2011) proposed a typology of truthful but misleading claims that integrate psychological theories with a legal framework. Five types were identified: omission of material facts, semantic confusion, intra-attribute misleadingness, misleadingness and source-based inference.

This form of deception is more difficult to detect because it requires a comparison between consumers beliefs formed from the message and the actual product or service attributes.

\section{Perceived Deception in Advertising: Definition and Existing Measurement Tools}

In this research, we are interested in the perception of deception in advertising defined as the extent to which a consumer believes that the ad in which he was exposed tends to mislead him.

According to Maddox (1982), perceived deception is based on whether the consumer can identify an ad that contains a claim that has been classified as misleading, deceptive or distorted 
(Maddox, 1982). In the domain of ecommerce, Román (2007) defined perceived deception as the extent to which the consumer believes that the online retailer use deceptive or manipulative practices with the intent to persuade consumers to purchase the website's offerings. In the same context, Xiao and Tan (2006) argued that perceived deception refers to "the consumer's belief, held without sufficient evidence to warrant certainty, that the product recommendation agent is being deceptive".

Two measures of perceived deception in advertising have been identified in the literature:

- A three-item, seven-point, bipolar scale from Maddox (19982). These items were tested by Newell et al. (1998) in the field of advertising and Grazioli and Jarvenpa
(2000) in the domain of e-commerce. Reliability and validity have been demonstrated through these two studies.

- A four-item Likert-type taken from the scale developed by Román (2007) to measure consumers' perceptions regarding the ethics of online retailers. The first item utilized in this measure "the site exaggerates the benefits and characteristics of its offerings" reflects a specific situation where deception is achieved through exaggeration. Therefore, it is not suitable for describing other forms of deception.

On the other hand, these measures offer a one-dimensional conceptualization of deception. Recent studies in the context of interpersonal communication have identified several facets of perceived deception (table 1).

Table 1: Themes Identified in Interpersonal Communication

\begin{tabular}{|c|c|l|}
\hline Concept & Authors & \multicolumn{1}{c|}{ Dimensions } \\
\hline $\begin{array}{c}\text { Customer } \\
\text { perception of } \\
\text { employee } \\
\text { deception }\end{array}$ & $\begin{array}{c}\text { Jhen and } \\
\text { Scott (2008) }\end{array}$ & $\begin{array}{l}\text { Four themes were identified: } \\
\text { - The players involved in the deception } \\
\text { - The type of perceived deceit: deception about beliefs, } \\
\text { intentions and emotions. } \\
\text { - The beneficiaries of deceit. } \\
\text { - The harm done by the perceived deceit. }\end{array}$ \\
\hline $\begin{array}{c}\text { Beliefs about } \\
\text { deceptive } \\
\text { communication } \\
\text { (from deceiver } \\
\text { perspective) }\end{array}$ & $\begin{array}{c}\text { Scholl and } \\
\text { O'Hair } \\
\text { (2005) }\end{array}$ & $\begin{array}{l}\text { - Intentionality: it is defined as the extent to which one } \\
\text { lacks a sense of self-awareness and personal agency when } \\
\text { engaging in deception. } \\
\text { - Ethic: it represents the extent to which one believes } \\
\text { deception is unacceptable and unethical communicative } \\
\text { behavior. } \\
\text { - Acceptance of deception: it represents the extent to } \\
\text { which deception is viewed as normative behavior. } \\
\text { - Upbringing: it refers to the extent to which upbringing } \\
\text { and formation has any bearing on how one views } \\
\text { deception as an acceptable and useful communication tool. }\end{array}$ \\
\hline
\end{tabular}

\section{Scale Development and Validation}

We propose in what follows to construct a multi-item scale to measure perceived deception in advertising based on the paradigm of Churchill (1979) and updated by Gerbing and Anderson (1988).

\section{Item Generation}

Items were generated on the basis of an exhaustive review of the literature completed by an exploratory qualitative study. Face to face semi-structured interviews were conducted with 42 Tunisians with diversified demographic 
profiles. The main topics discussed were linked to perceptions and the reactions of respondents to advertising deception (table 2).

\section{Table 2: Interview Guide}

- What do you think about advertising in general?

- Have you recently met ads you have judged to be misleading?

- What forms of deception are there in these ads? Are they always easy to identify? Why?

- For what type of products advertising seems more misleading?

- What do you think about the use of deception in advertising for professionals and consumers?

- What are your reactions to these deceptions?

- Do you think it is possible to accept deception in advertising? To what extent can the use of deception be considered as tolerable?

After the elimination of the redundant propositions, a list of 25 items (Appendix 1) were selected and inserted in the questionnaire for data collection.

\section{First Study and Purification of Measure}

\section{$>$ Choice of Advertising Stimuli and Data Collection}

For the selection of advertising stimuli, nine ads were submitted for evaluation by 20 respondents regarding the level of deception found in each. In this research, our interest is around consumer perceptions of advertising deception rather than actual deception. So it is important that the selected ads are deemed deceptive on the part of persons who are exposed on these ads.

Four advertisements were finally selected for this study taken from two Tunisian magazines "Livret Santé" and "Magalogue Tendance" (Appendix 2). Following the same procedure adopted by Sabri (2007) and De Pelsmacker and Van Den Bergh (1996) in the selection of stimuli, we have retained for each type of deception two ads reflecting each a low or high perception to generate variance.

Data collection was conducted among a convenience sample composed of 118 individuals (Appendix3). They were invited to observe one of four ads selected and express their degree of agreement with the 25 items on the basis of 5 point Likert-type scale from " 1 = strongly disagree" to " $5=$ strongly agree".

\section{$>$ Factor and Items Analysis}

To make an initial purification of the selected items, exploratory factor analysis was conducted by means of spss 19 . This aims at summarizing the data collected and examining the dimensional structure of the measurement scale. Principal components factor analysis using an oblique rotation (oblimin direct) was made. Conditions of the application of this analysis were performed by examining the correlation matrix, the Kaiser-Meyer-Olkin (KMO) index and Bartlett's Test of sphericity. The KMO measure of sampling adequacy was 0.856 indicating the extent to which variables selected form a coherent set and adequately measure the concept (Carricano et al., 2010). The Bartlett's test of sphericity was also significant ( $p=0.000)$. Items that were eliminated are those whose communality is lower than 0.5 and those that do not saturate on a single factor (Evrard et al., 2003).

The final structure emerged from our exploratory analysis revealed two factors (table 3): 
- The first factor "perceived veracity" consists of four items accounting for $52.82 \%$ of the variance. These items describe the extent to which consumers believe that the content of the ad does not reflect the veracity. The first item was taken from the scale used by Román
(2010) to measure perceived deception in online shopping.

- The second factor "ethic" explains 14.41 $\%$ of the variance. It consists of four items that refer to the extent to which consumers believe that deception is an unethical act that may harm their interests and those of competitors.

Table 3: Results of the Exploratory Factor Analysis after Items Purification (Study 1; N = 118)

\begin{tabular}{|c|c|c|c|c|c|}
\hline $\begin{array}{l}\text { Factor } \\
\mathrm{s}\end{array}$ & Formulation of items & Loading & $\begin{array}{l}\text { Communal } \\
\text { ity }\end{array}$ & $\begin{array}{c}\% \text { of } \\
\text { explaine } \\
d \\
\text { variance } \\
\end{array}$ & $\begin{array}{l}\text { Cronbach } \\
\text { 's alpha }\end{array}$ \\
\hline \multirow{4}{*}{ F1 } & $\begin{array}{l}\text { - This ad is not entirely truthful about its } \\
\text { offerings. }\end{array}$ & 0.879 & 0.702 & \multirow{4}{*}{52.823} & \multirow{4}{*}{0.830} \\
\hline & $\begin{array}{l}\text { - This ad shows to individual what he } \\
\text { wants to see and not the reality. }\end{array}$ & 0.802 & 0.604 & & \\
\hline & $\begin{array}{l}\text { - I think that the reality is different from } \\
\text { what it is mentioned in the ad. }\end{array}$ & 0.739 & 0.639 & & \\
\hline & $\begin{array}{l}\text { - This ad misleads consumer about the } \\
\text { actual performances of the product. }\end{array}$ & 0.739 & 0.736 & & \\
\hline \multirow{4}{*}{ F2 } & - This ad harms consumer' interests. & 0.873 & 0.714 & \multirow{4}{*}{14.415} & \multirow{4}{*}{0.831} \\
\hline & $\begin{array}{l}\text { - This ad is contrary to the principles of } \\
\text { fair competition. }\end{array}$ & 0.837 & 0.636 & & \\
\hline & - This ad is dishonest. & 0.746 & 0.656 & & \\
\hline & - This ad is trying to dupe the consumer. & 0.678 & 0.692 & & \\
\hline & KMO & \multicolumn{2}{|c|}{0.856} & & \\
\hline Sig. & $\begin{array}{c}\text { Bartlett's Test of sphericity } \\
\text { Approx. Khi-Square }\end{array}$ & \multicolumn{2}{|c|}{$\begin{array}{c}416.006 \\
0.000\end{array}$} & & \\
\hline
\end{tabular}

\section{Second Study and Confirmatory Analysis}

In order to validate the factor structure of the scale, a new data collection was conducted among 203 individuals on the basis of the same advertisements. Confirmatory factor analysis (CFA) was carried out using AMOS 20. The method of estimation mobilized is Maximum Likelihood estimation which requires verification of certain conditions including the size of the sample and the respect of multi-normality. This is tested through the coefficient of symmetry (Skewness) which must not exceed 3 in absolute value and the kurtosis coefficient which must not exceed 8 in absolute value (Roussel et al., 2002). Values obtained in this research turn out to be applying to the standards. However the value of Mardia's coefficient is 15,662 > 3 (Roussel et al., 2002).

Hence, we carry out the re-estimation of the measurement model with the bootstrap procedure by setting the number of bootstrap samples to 250 as suggested by Nevitt and Hancock (2000) (cited by Akrout, 2010). The results before and after the procedure of bootstrap are very close. In fact, the test of bias is not significant for most variables. So, there is a weak effect of the deviation of variables of the normal distribution on the estimates.

\section{$>$ Assessing the Model Fit}

In order to assess how well the model matches the observed data, we use several 
fit indexes that can be classified into 3 categories:

- Absolute fit indices: they measure the ability of the model to fit the data. The indices examined are chi-square, chisquare/ddl, GFI, AGFI, RMR and RMSEA.

- Incremental fit indices: they evaluate the improvement of the fit of a model by comparing it to a more restrictive model called "baseline model" (Bentler, 1990 cited by Roussel and Wacheux, 2005). The indices utilised are NFI, CFI and TLI.

- Parsimony fit indices: these indices are used to evaluate the fit of each estimated parameter and to avoid overestimating a model with parameters that would provide a marginal gain to the adjustment (Roussel and Wacheux, 2005). We examined in our research the following indices: ECVI, PNFI, AIC and CAIC.

The results of the confirmatory factor analysis for the second-order model (Appendix 4) demonstrate the significance of the indices and a good fit of the model (table 4). Key values are from Roussel et al. (2002). Indeed, the use of a second-order factor analysis will help to highlight the structural relationship between the dimensions (Hair et al., 1998). It is justified by a theatrical framework demonstrating the existence of dimensions of perceived deception and an important correlation (in our research it is equal to 0.681 ) between the factors (Roussel et al., 2002).

Table 4: The Fit Indices of Structural Equation Model of the Scale

\begin{tabular}{|c|c|c|c|}
\hline $\begin{array}{l}\text { Type of } \\
\text { indices }\end{array}$ & $\begin{array}{c}\text { Name of the } \\
\text { indices }\end{array}$ & Key values & Values obtained \\
\hline \multirow{6}{*}{$\begin{array}{l}\text { Absolute fit } \\
\text { indices }\end{array}$} & Chi-square & None ( $\mathrm{p}$ associated) & $29.824(0.054)$ \\
\hline & Chi-square/ddl & Between 1 and 2 & $29.824 / 19=1.570$ \\
\hline & GFI & $>0.9$ & 0.967 \\
\hline & AGFI & $>0.9$ & 0.937 \\
\hline & RMR & Nearest to 0 & 0.055 \\
\hline & RMSEA & $<0.08$ and if possible $<0.05$ & 0.053 \\
\hline \multirow{3}{*}{$\begin{array}{l}\text { Incremental } \\
\text { fit indices }\end{array}$} & NFI & $>0.9$ & 0.967 \\
\hline & CFI & $>0.9$ & 0.987 \\
\hline & TLI & $>0.9$ & 0.982 \\
\hline \multirow{4}{*}{$\begin{array}{l}\text { Parsimony } \\
\text { fit indices }\end{array}$} & ECVI & $\begin{array}{l}\text { The lowest possible } \\
\text { (comparison with the independent model) }\end{array}$ & $\begin{array}{l}0.316 \\
(<4.503)\end{array}$ \\
\hline & PNFI & $\begin{array}{l}\text { The highest possible } \\
\text { (comparison with the independent model) }\end{array}$ & $\begin{array}{l}0.656 \\
(>0.000)\end{array}$ \\
\hline & AIC & $\begin{array}{l}\text { The lowest possible } \\
\text { (comparison with the independent model) }\end{array}$ & $\begin{array}{l}63.824 \\
(<909.695)\end{array}$ \\
\hline & CAIC & $\begin{array}{l}\text { The lowest possible } \\
\text { (comparison with the independent model) }\end{array}$ & $\begin{array}{l}137.148 \\
(<944.201)\end{array}$ \\
\hline
\end{tabular}

\section{$>$ Scale Reliability}

To assess the reliability of the measurement scale, we used Cronbach's alpha and Jöreskog's rho. The later is less sensitive to the number of items analysed (Fornell and Larker, 1981). A rho value greater than 0.7 or 0.8 , depending on the authors, is considered as acceptable (Fornell and Larker, 1981). The results presented in table 5 show that the value of
Cronbach's alpha is greater than 0.8 for the two axes. The value of Jöreskog's rho is equal to 0.786 for the first factor and 0.819 for the second factor. We can then attest the reliability of our scale.

\section{$>$ Scale Validity}

We are interested in the trait and the predictive validity of the scale developed to measure deception in advertising. 
- Trait validity allows the verification of whether the indicators created are a good representation of the phenomenon studied (Evrard et al., 2003). Two forms are examined:

$\Rightarrow$ Convergent Validity: it determines the extent to which the measures for the same concept by two different methods are convergent (Akrout, 2010). Convergent validity was assessed by calculating the rho of convergent validity which must be greater than 0.5 (Fornell and Larker, 1981). The results presented in table 6 show an acceptable value for the second factor ( $\rho v c$ $\mathrm{F} 2=0.533$ ) and a value slightly lower than the recommended threshold for the first factor $\left(\rho \mathrm{vc}_{\mathrm{F} 1}=0.480\right)$.

Table 5: Reliability and Convergent Validity

\begin{tabular}{|c|c|c|c|}
\hline \multirow{2}{*}{ Factors } & \multicolumn{2}{|c|}{ Reliability } & Convergent validity \\
\cline { 2 - 4 } & Cronbach's alpha & Jöreskog's rho & Rho of convergent validity $\boldsymbol{\rho}_{\mathbf{v c}}$ \\
\hline F1 & 0.867 & 0.786 & 0.480 \\
\hline F2 & 0.870 & 0.819 & 0.533 \\
\hline
\end{tabular}

$\Rightarrow$ Discriminant Validity: it was tested by verifying that the average variance extracted $(\rho v c)$ by each construct $\left(\rho v c_{\mathrm{F} 1}=\right.$ 0.480 et $\rho \mathrm{vc}_{\mathrm{F} 2}=0.533$ ) was greater than the squared structural link between the two constructs $(\Phi 2 \mathrm{~A} 1 \mathrm{~A} 2=0.463)$ (Fornell and Larker, 1981).

Table 6: Discriminant Validity

\begin{tabular}{|l|l|l|}
\hline & \multicolumn{1}{|c|}{ Factor 1 } & \multicolumn{1}{c|}{ Factor 2 } \\
\hline \multirow{2}{*}{ Factor 1 } & $\rho_{\mathrm{vc}}$ & \\
& 0.480 & $\rho_{\mathrm{vc}}$ \\
\hline \multirow{2}{*}{ Factor 2 } & $\Phi^{2} \mathrm{~A} 1 \mathrm{~A} 2$ \\
& $(0.681)^{2}=0.463$ & 0.533 \\
\hline
\end{tabular}

- Predictive Validity: it aims at checking whether the relationship between the measures of a concept and those of other concepts are consistent with the predictions from the theory (Evrard et al., 2003). In this research, predictive validity was examined by studying the relationship between perceived deception and attitude toward the ad. In the literature, a negative relationship was shown between the two concepts (Newell et al., 1996). The results of the new confirmatory analysis revealed that the fit indices were satisfactory (Table 7).

Table 7: Indicators of Model Fit of the Effect of Perceived Deception in Advertising on the Attitude toward the Ad

\begin{tabular}{|c|c|c|c|c|c|c|c|c|c|c|c|c|}
\hline $\mathbf{x}^{2}$ & $\begin{array}{c}\mathbf{x}^{\mathbf{2}} / \\
\mathbf{d d l}\end{array}$ & $\mathbf{G F I}$ & $\begin{array}{c}\text { AG } \\
\text { FI }\end{array}$ & $\begin{array}{c}\mathbf{R M} \\
\mathbf{R}\end{array}$ & $\begin{array}{c}\text { RMS } \\
\text { EA }\end{array}$ & NFI & CFI & TLI & ECVI & PNFI & AIC & CAIC \\
\hline 90.8 & 1.74 & 0.9 & 0.8 & 0.0 & 0.06 & 0.9 & 0.9 & 0.9 & $\begin{array}{c}0.707 \\
(<7.5\end{array}$ & $\begin{array}{c}0.740 \\
(>0.0 \\
00\end{array}$ & $\begin{array}{c}142.873 \\
(<1524 . \\
145)\end{array}$ & $\begin{array}{c}255.016 \\
(<1575 . \\
904)\end{array}$ \\
\hline
\end{tabular}

In addition, the model results presented in Figure 1 confirm the negative impact of deception on perceived attitude toward the ad. 


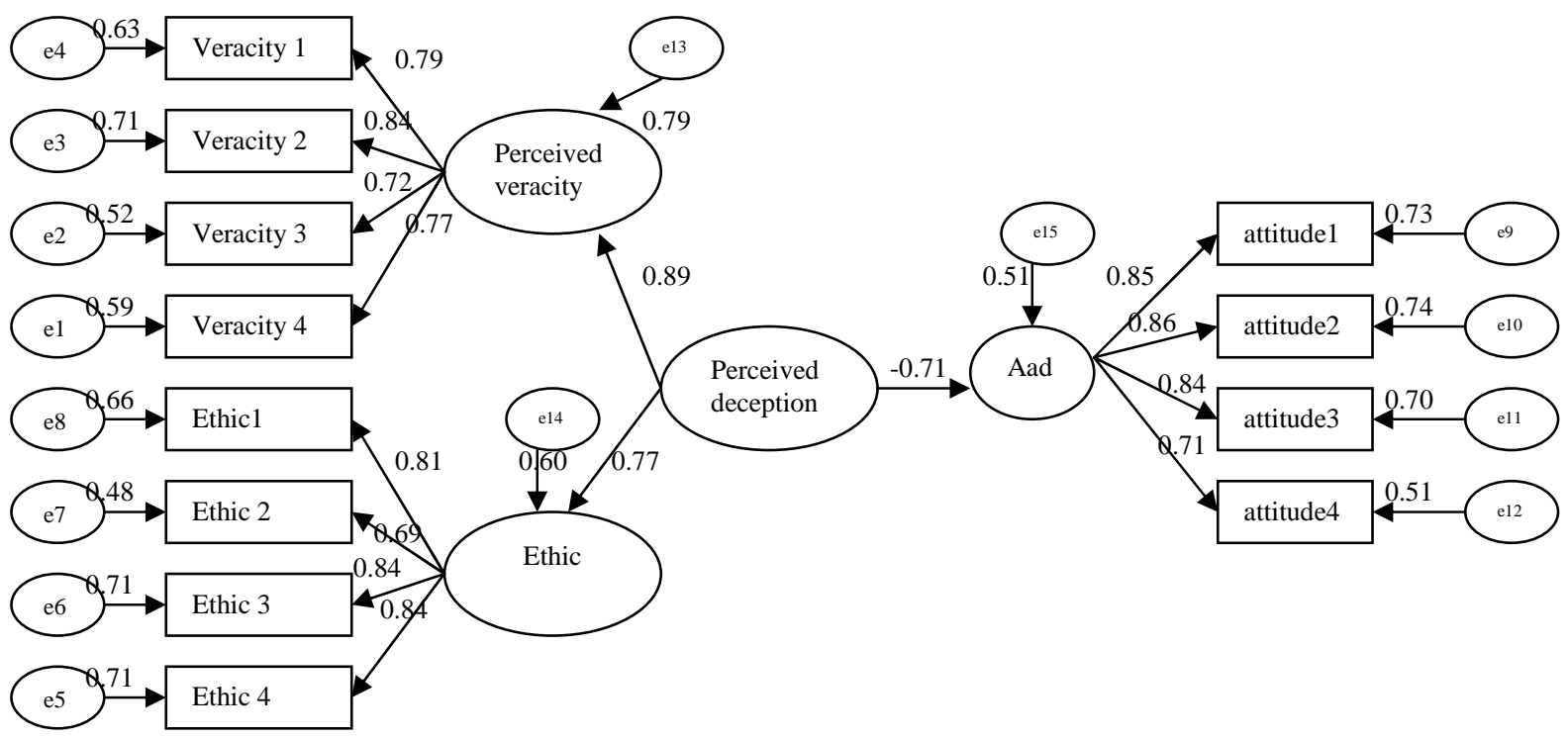

Figure 1: Structure of Perceived Deception and Its Effect on the Attitude toward the Ad

\section{Conclusion}

This research has the advantage of reaching a better conceptualization of deception in advertising. Referring to the literature in social psychology and advertising, characteristics and forms of deception were identified. Subsequently, a measure of perceived deception has been proposed and validated, based on the recommendations of Churchill (1979) and Gerbing and Anderson (1988).

From a theatrical viewpoint, this work provides a better understanding of the concept of deception. It offers the first multi-dimensional measurement scale of perceived deception in advertising. The first dimension "perceived veracity" is related to the degree of truthfulness estimated by the person exposed to the ad. The second dimension "ethic" reflects the extent to which deception in advertising is seen as an unethical practice that may harm consumers and competitors.

From a managerial point of view, this scale is useful for marketing practitioners. It can be used as an indicator of the degree of deception actually judged by consumers. It also allows managers to identify the message elements perceived as deceptive and make necessary corrections. Indeed, even if deception is unintentional consumers may manifest a negative reaction when they perceive the ad as deceptive.

The main limitation of this research is that the scale was tested with forms of deceptive advertising practices. It would be interesting to carry out studies on other forms of deception by referring to other communication media. Moreover, it would be important to test the stability of the scale in other cultural contexts.

On the other hand, it is also interesting to identify the variables that can influence the perception of deception in advertising, test them in a conceptual model and test the effect of certain moderating variables such as the acceptance of deception, product implication and emotion.

\section{References}

Aditya, R. N. (2001). "The Psychology of Deception in Marketing: A Conceptual Framework for Research and Practice," Psychology \& Marketing, Vol. 18, Iss. 7, Pg. 735.

Akrout, F. (2010). 'Les Méthodes Des Equations Structurelles,' 1ère Edition, 273 Pages. 
Anderson, J. C. \& Gerbing, D. W. (1982). "Some Methods for Respecifying Measurement Models to Obtain Unidimensional Construct Measurement," Journal of Marketing Research, 19, 453-460.

Armstrong Gary, M. \& Mclennan, James, P. (1973). 'The Federal Trade Commission and the Investigation and Regulation of Deception in Advertising,' In Increasing Marketing Productivity/Conceptual and Methodological Foundations of Marketing, Ed. Thomas U. Greer, Chicago: American Marketing Association, 430-434.

Armstrong Gary, M. \& Russ Federick, A. (1975). 'Detecting Deception in Advertising,' MSU Business Topics, 23, 2131

Boush, D. M., Friestad, M. \& Wright, P. (2009). Deception in the Marketplace: The Psychology of Deceptive Persuasion and Consumer Self-Protection, Routledge, 264 Pages.

Buller, D. B. \& Burgoonm, J. K. (1996). "Interpersonal Deception Theory," Communication Theory, 6(3), 203-242.

Carricano, M., Poujol, F. \& Bertrandias, L. (2010). Analyse De Données Avec SPSS, Pearson Education France, Paris, 2ème Edition 2010 - 248 Pages.

Carson Thomas, L., Wokutch Richard, E. \& Cox, Jr. James E. (1985). "An Ethical Analysis of Deception in Advertising," Journal of Business Ethics, Vol. 4, Pp. 93104.

Churchill, G. A. (1979). "A Paradigm for Developing Better Measures of Marketing Constructs," Journal of Marketing Research, Février, 16, 64-73.

Darke Peter, R. \& Ritchie Robin, J. B. (2007). "The Defensive Consumer: Advertising Deception, Defensive Processing and Distrust," Journal of Marketing Research, 44, 1, Pp. 114-127.

Depaulo, B. M., Ansfield, M. E. \& Bell, K. L. (1996). "Theories About Deception and Paradigms for Studying It: A Critical
Appraisal of Buller and Burgoon's Lnterpersonal Deception Theory and Research," Communication Theory, 6(3), 297-310.

Depaulo, B. M., Lindsay, J. J., Malone, B. E., Muhlenbruck, L., Charlton, K. \& Cooper, H. (2003). "Cues to Deception," Psychology Bulletin, 129(1), 74-118.

De Pelsmacker, P. \& Van Den Bergh, J. (1996). "The Communication Effects of Provocation in Print Advertising," International Journal of Advertising, Vol. 15, Iss. 3; Pp. 203-237.

Didellon, L. \& Valette-Florence, P. (1996). 'L'utilisation Des Indices D'ajustement Dans Les Modèles D'équations Structurelles: Présentation et Recommandations D'usage,' Actes Des Xiièmes Journées Des IAE, 111-125.

Ekman, P. (1992). Telling Lies, Clues to Deceit in the Marketplace, Politics and Marriage (2nd. Ed.), New York: W. W. Norton\&Company.

Ekman, P. \& Frieson, W. V. (1969). "Nonverbal Leakage and Clues to Deception," Psychiatry, 32, 88-106.

Estrada, M. L. (2006). "The Impact of Deceptive Advertising on Corporate Sales," Honors Thesis, California University, Long Beach, $C A$.

Ford, C. V. (1996). Lies !Lies!!Lies!!!The Psychology of Deceit, Washington, DC: American Psychiatric Press.

Fornell, C. \& Bookstein, F. L. (1982). "Two Structural Equation Models : LISREL and PLS Applied to Consumer Exit-Voice Theory," Journal of Marketing Research, 19, 440-452.

FTC (1983). FTC Policy Statement on Deception, Retrieved April 26, 2012, from http://ftc.gov/bcp/policystmt/addecept.htm/

Gao Zhihong (2008). "Controlling Deceptive Advertising in China: An Overview," Journal 
of Public Policy \& Marketing, Vol. 27 (2), Pp. 165-177.

Gardner David, M. (1975). "Deception in Advertising: A Conceptual Approach," Journal of Marketing, Vol. 39, Pp. 40-46.

Gerbung, D. W. \& Anderson, J. C. (1988). "An Updated Paradigm for Scale Development Incorporating Unidimensionality and Its Assessment," Journal of Marketing Research, 25, 186-192.

Grazioli, S. \& Jarvenpa, S. L. (2000). "Perils of Internet Fraud: An Empirical Investigation of Deception and Trust with Experienced Internet Consumers," IEEE Transactions on Systems, Man and Cybemetics, 30, 395-410.

Grazioli, S. \& Jarvenpa, S. L. (2003). "Consumer and Business Deception over the Internet: Content Analysis of Documentary Evidence," International Journal of Electronic Commerce, 7, 93-118.

Hair, J. F., Anderson, R. E., Tatham, R. L. \& Black, W. C. (1998). Multivariate Data Analysis, 5e Éds., New Jersey, Prentice-Hall Inc.

Hastak Manoj \& Mazis Michael, B. (2011). "Deception by Implication: A Typology of Truthful but Misleading Advertising and Labelling Claims," Journal of Public Policy \& Marketing.

Hyman, M. R., Tansey, R. \& Clark, J. W. (1994). "Research on Advertising Ethics: Past, Present and Future," Journal of Advertising, Vol.23, No. 3, Pg 5.

Jhen, K. A. \& Scott, E. D. (2008). "Perceptions of Deceptions: Making Sense of Responses to Employee Deceit," Journal of Business Ethics, 80, 327-347.

Kerr, P. (1990). 'The Penguin Book of Lies,' London: Penguin Books.

Köhnken, G. (1989). 'Behavioral Correlates of Statement Credibility: Theories, Paradigms and Results,' In H. Wegener F., Lösel et Haisch (Eds), Criminal Behaviour and the Justice System (Pp. 271-289), London: Springer Verlag.

Lord, K. R. \& Kim, C. K. (1995). "Inoculating Consumers Against Deception: the Influence of Framing and Evectional Style," Journal of Consumer Policy, Vol. 18, Pp. 123.

Maddox, R. N. (1982). "The Structure of Consumers' Satisfaction: Cross Product Comparisons," Journal of the Academy of Marketing Science, 10, 37-53.

Masip Jaune, Garrido Eugenio \& Herrero Carmen (2004). "Defining Deception," Anales De Psicologia, Vol. 20, No. 1, Pp. 147171.

McCornack, S. A. (1992). "Information Manipulation Theory," Communication Monographs, 59(1), 1-16.

Miller, G. R. (1983). 'Telling It Like It Isn't and Not Telling It Like It Is: Some Thoughts on Deceptive Communication,' In J. I. Sisco (Ed.), The Jensen Lectures (Pp. 91-116). Tampa, FI University of South Florida.

Nevitt, J. \& Hancock, G. R. (2000). "Improving the Root Mean Square Error of Approximation for Nonnormal Conditions in Structural Equation Modeling," Journal of Experimental Education, 68, 251-268.

Newell, S. J., Goldsmith, R. E. \& Banzhaf, E. J. (1998). "The Effect of Misleading Environmental Claims on Consumer Perceptions of Advertisements," Journal of Marketing Theory and Practice, 6, 2, Pg. 48.

Nyberg, D. (1993). The Varnished Truth: Truth Telling and Deceiving In Ordinary Life, Chicago, IL: University of Chicagi Press.

Olson, J. C. \& Dover, P. A. (1978). "Cognitive Effects of Deceptive Advertising," Journal of Marketing Research, Vol. 15, Pp. 29-38.

Pras, B., Evrard, Y. \& Roux, E. (2003). MARKET : Etudes et Recherches en Marketing, Fondements, Méthodes, 3ème Edition, Dunod Paris. 
Román, S. (2007). "The Ethics of Online Retailing: A Scale Development and Validation from the Consumers' Perspective," Journal of Business Ethics,72, 131-148.

Román, S. (2010). "Relational Consequences of Perceived Deception in Online Shopping: The Moderating Roles of Type of Product, Consumer's Attitude Toward Internet and Consumer's Demographics," Journal of Business Ethics, 95, 373-391.

Romani, S. (2006). "Price Misleading Advertising: Effects on Trustworthiness Toward the Source of Information and Willingness to Buy," Journal of Product \& Brand Management, 15, 2, Pp. 130-138.

Roussel, P., Durieu, F., Campoy, E. \& El Akremi, A. (2002). Méthodes D'équations Structurelles: Recherches et Applications En Gestion, Paris, Economica.

Roussel, P. \& Wacheux, F. (2005). Management Des Ressources Humaines: Méthodes De Recherche En Sciences
Humaines et Sociales, Publié Par De Boeck Université, 448 Pages.

Russo Edward, J., Metcalf Barbara, L. \& Stephens Debra (1981). "Identifying Misleading Advertising," Journal of Consumer Research, Vol. 8, Pg. 119.

Sabri-Zaaraoui, O. (2007). Le Tabou En Communication Publicitaire: Conceptualisation, Mesure et Application, Actes Du Xxiiie Congrès AFM, Aix-Les-Bains.

Scholl, J. C. \& O’Hair, D. (2005). "Uncovering Beliefs about Deceptive Communication," Communication Quaterly, Vol. 53, No. 3, Pp. 377-399.

Serban, G. (2001). 'Lying-Man's Second Nature,' Westport, CT: Praeger.

Xiao, B. \& Tan, C. (2006). "Reducing the Perceived Deception of Product Recommendation Agent: The Impact of Perceived Verifiability and Perceived Similarity," Proceedings of the Fifth Annual Workshop on HCI Research in MIS, Milwaukee, WI, December 9, 2006. 


\section{Appendix 1: List of Items Selected for the First Data Collection}

\begin{tabular}{|c|c|}
\hline Dimensions & List of propositions \\
\hline $\begin{array}{c}\text { Perceived } \\
\text { veracity }\end{array}$ & $\begin{array}{l}\text { - This ad tries to convince the consumer by a lie. } \\
\text { - This ad falsifies the actual characteristics of the product. } \\
\text { - This ad is not entirely truthful about its offerings. } \\
\text { - The information in this ad is not logically acceptable. } \\
\text { - The information in this ad is exact. (-) } \\
\text { - I think that the reality is different from what it is mentioned in the ad. } \\
\text { - The quality of information is manipulated in this ad. } \\
\text { - This ad uses deceptive tactics to convince consumers to buy the product. } \\
\text { - This ad tries to convince consumers by exaggerating the benefits and } \\
\text { characteristics of its offerings. }\end{array}$ \\
\hline Consequences & $\begin{array}{l}\text { - This ad leads to distort a perception of reality. } \\
\text { - This ad led to a misinterpretation of the information presented. } \\
\text { - This ad misleads consumer about the actual performances of the product. } \\
\text { - This ad tries to persuade consumers to buy things he does not need. }\end{array}$ \\
\hline Ethic & $\begin{array}{l}\text { - This ad is unethical. } \\
\text { - This ad is fraudulent. } \\
\text { - This ad is trying to dupe the consumer. } \\
\text { - This ad harms consumer' interests. } \\
\text { - This ad is contrary to the principles of fair competition. . } \\
\text { - This ad harms competing products. } \\
\text { - This ad is dishonest. }\end{array}$ \\
\hline Vulnerability & $\begin{array}{l}\text { - This ad takes advantage of less experienced consumers to make them } \\
\text { purchase. } \\
\text { - This ad shows to the individual what he wants to see and not the reality. }\end{array}$ \\
\hline Legal aspect & $\begin{array}{l}\text { - This ad does not respect laws. } \\
\text { - This ad should be judicially sanctioned. } \\
\text { - This ad needs to be regulated. }\end{array}$ \\
\hline
\end{tabular}


Appendix 2: The Advertising Stimuli Used in the Two Surveys

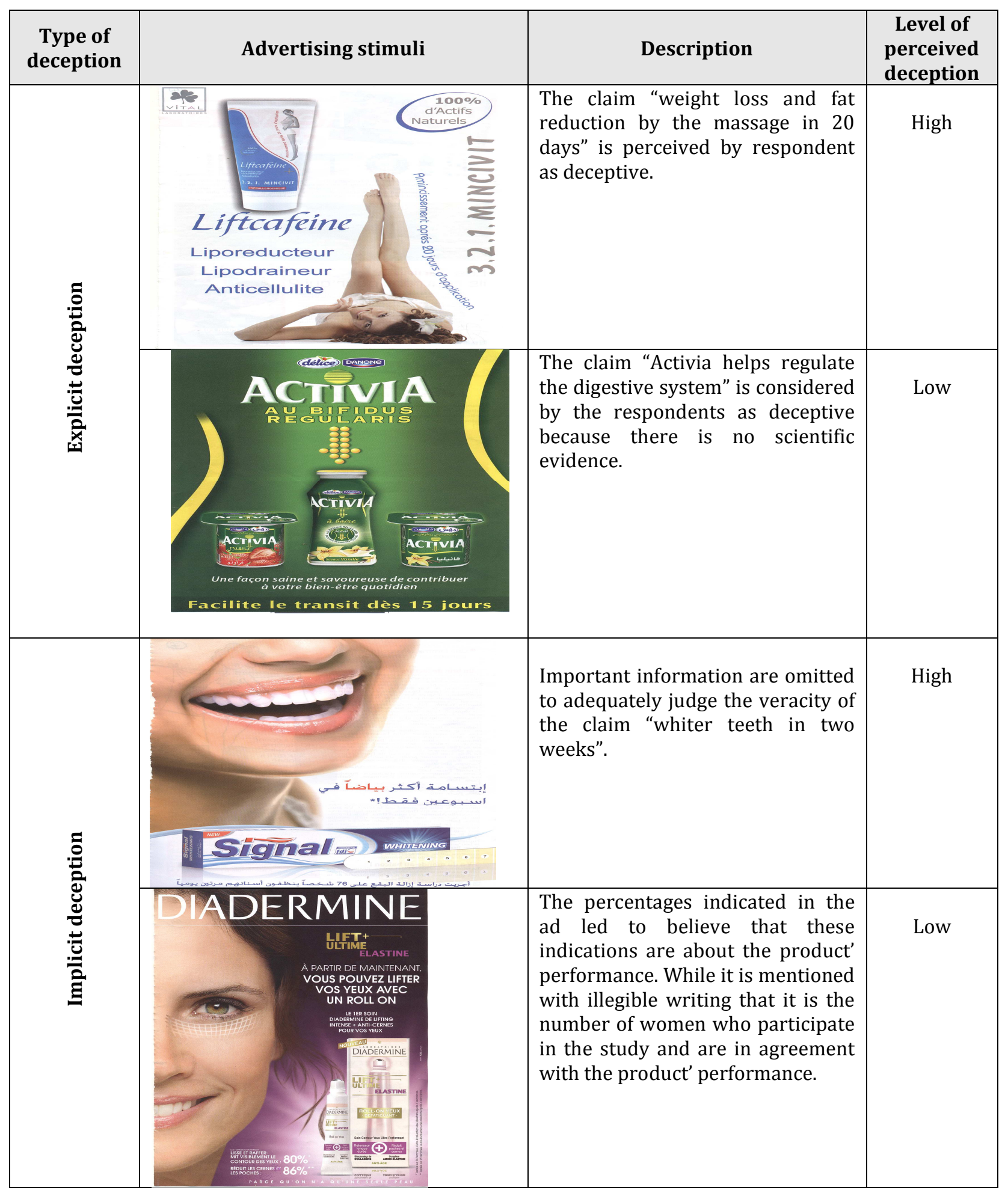


Appendix 3: Characteristics of the Sample

\begin{tabular}{|c|l|c|c|}
\hline \multirow{2}{*}{ Criterion } & \multicolumn{1}{|c|}{ Categories } & \multicolumn{2}{|c|}{ Proportions (\%) } \\
\cline { 2 - 4 } & & Study 1 & Study 2 \\
\hline \multirow{4}{*}{ Age } & Less than 20 & 6,8 & 1.5 \\
\cline { 2 - 4 } & From 21 to 30 years & 50,8 & 64 \\
\cline { 2 - 4 } & From 31 to 40 years & 16,1 & 22.7 \\
\cline { 2 - 4 } & From 41 à 50 years & 12,7 & 8.4 \\
\cline { 2 - 4 } & From 51 to 60 years & 13,6 & 3.4 \\
\hline \multirow{4}{*}{ Profession } & Senior executive & 32,2 & 15.8 \\
\cline { 2 - 4 } & Junior executive & 20,3 & 10.8 \\
\cline { 2 - 4 } & Employee & 2,5 & - \\
\cline { 2 - 4 } & Teacher & 6,8 & 20.2 \\
\cline { 2 - 4 } & Student & 26,3 & 48.3 \\
\cline { 2 - 4 } & Liberal profession & 10,2 & 4.9 \\
\cline { 2 - 4 } & Housewife & 1,7 & - \\
\hline \multirow{2}{*}{ Sexes } & Man & 46,6 & 56.3 \\
\cline { 2 - 4 } & Woman & 53,4 & \\
\hline
\end{tabular}

Appendix 4: Modelling Perceived Deception in Advertising as a Reflective Second-Order Factor

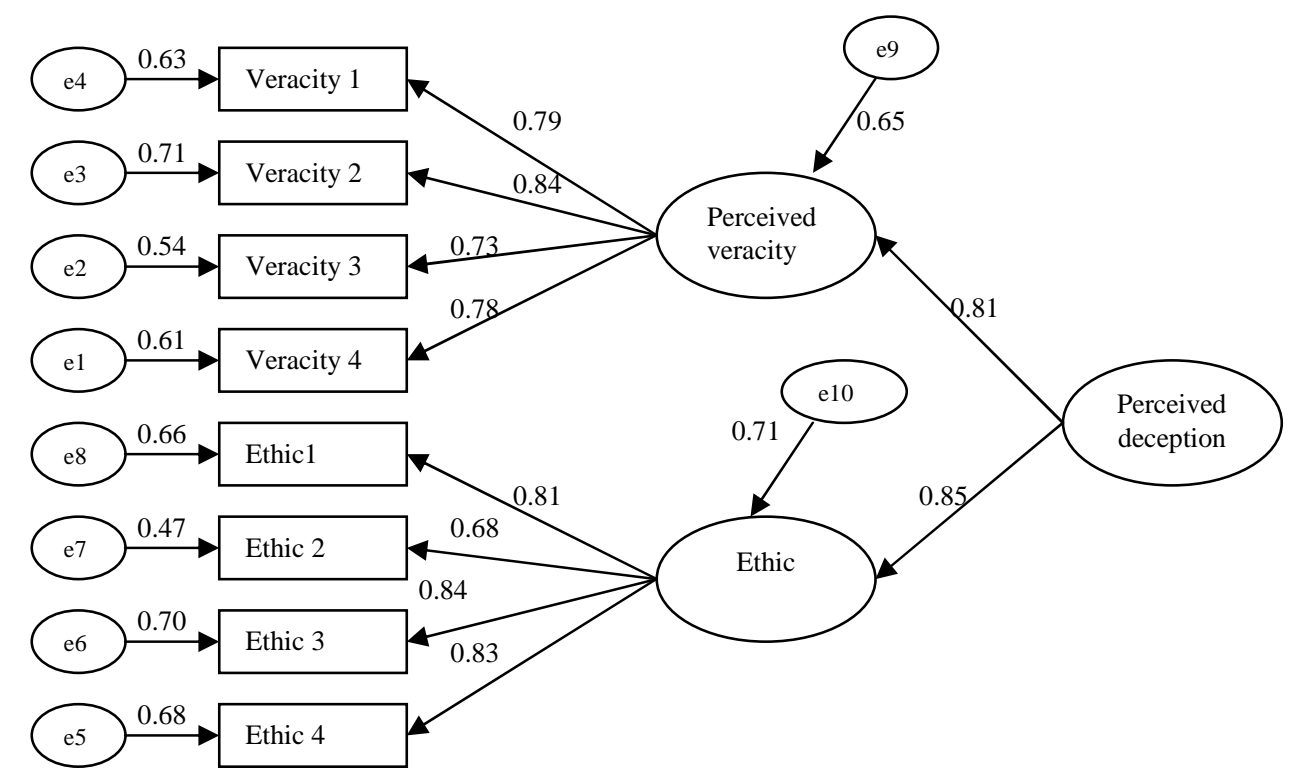

